\title{
ZWOLNIENIE PRACOWNIKA Z OBOWIĄZKU ŚWIADCZENIA PRACY W OKRESIE WYPOWIEDZENIA
}

I. Zwolnienie pracownika $\mathrm{z}$ obowiązku świadczenia pracy w okresie wypowiedzenia jest praktyką coraz częściej stosowaną przez pracodawców, zwłaszcza w stosunku do pracowników zarządzających zakładem pracy lub pracowników na stanowiskach kierowniczych. Ukształtowanie się tej instytucji na współczesnym rynku pracy zostało podyktowane uzasadnionymi potrzebami stron stosunku pracy, wynikającymi z praktyki obrotu gospodarczego. Z punktu widzenia pracodawcy, zwolnienie pracownika $\mathrm{z}$ obowiązku świadczenia pracy $\mathrm{w}$ okresie wypowiedzenia pozwala na uniknięcie ryzyka związanego $\mathrm{z}$ niesumiennym lub niestarannym wykonywaniem przez pracownika pracy w tym okresie czy nawet ryzyka umyślnego działania na niekorzyść pracodawcy i zazwyczaj poprzedzone jest utratą zaufania do tego pracownika związana $\mathrm{z}$ wypowiedzeniem mu umowy o pracę. Odsunięcie pracownika od pracy w okresie wypowiedzenia leży również w interesie pracodawcy ze względów organizacyjnych, umożliwia bowiem natychmiastowe przejęcie obowiązków odchodzącego pracownika przez inną osobę i pozwala z jednej strony - na zapewnienie ciągłości procesu pracy, z drugiej zaś - na zminimalizowanie negatywnego wpływu, jaki odejście pracownika wywiera na atmosferę panująca w zakładzie pracy. Z tych względów zastosowanie instytucji zwolnienia pracownika z obowiązku świadczenia pracy w okresie wypowiedzenia, pomimo zapłaty temu pracownikowi w tym okresie wynagrodzenia za pracę, jest dla pracodawcy generalnie korzystne. Pracownikowi takie zwolnienie może również przynosić określone korzyści, zwłaszcza finansowe, w postaci otrzymania wynagrodzenia za prace mimo rzeczywistego jej niewykonywania $\mathrm{w}$ okresie wypowiedzenia, jak również faktyczne - przez zapewnienie w tym okresie, w zależności od konkretnych potrzeb, odpoczynku bądź czasu wolnego na poszukiwanie nowej pracy. Z drugiej jednak strony, pracownikowi może zależeć na faktycznym świadczeniu pracy również w okresie wypowiedzenia, w szczególności wtedy, gdy ciągłość wykonywania przez niego pracy wpływa na jego uprawnienia zawodowe czy pozwala na zachowanie dotychczasowego poziomu kwalifikacji zawodowych, zwłaszcza umiejętności.

Ukształtowanie się praktyki zwolnienia pracownika $\mathrm{z}$ obowiązku świadczenia pracy w okresie wypowiedzenie spowodowało, iż wskazana instytucja została również dostrzeżona w poglądach doktryny oraz judykaturze. De lege 
lata $\mathrm{w}$ Kodeksie pracy ${ }^{1}$ brak jest ogólnego przepisu statuującego instytucję zwolnienia pracownika $\mathrm{z}$ obowiązku świadczenia pracy $\mathrm{w}$ okresie wypowiedzenia. Takowa instytucja została expressis verbis przewidziana w art. 71 k.p. wyłącznie w odniesieniu do pracownika odwołanego ze stanowiska, którego w okresie wypowiedzenia pracodawca może - na wniosek pracownika lub za jego zgodą - zatrudnić przy innej pracy, odpowiedniej ze względu na jego kwalifikacje zawodowe. W tym okresie, pomimo faktycznego niewykonywania pracy, odwołany pracownik ma prawo do wynagrodzenia w wysokości przysługującej przed odwołaniem (stosownie do art. $70 § 2$ k.p.). Na mocy art. 72 ustawy z 21 listopada 2008 r. o służbie cywilnej² możliwość zwolnienia $\mathrm{z}$ pełnienia obowiązków $\mathrm{w}$ okresie wypowiedzenia, z zachowaniem prawa do wynagrodzenia, została wprost przewidziana także w stosunku do członka korpusu służby cywilnej. Ze wskazanych powyżej przepisów a contrario można wnioskować, że ustawodawca nie dopuszcza zwolnienia $\mathrm{z}$ obowiązku świadczenia pracy w okresie wypowiedzenia pozostałych kategorii pracowników ${ }^{3}$. Powyższa konstatacja nie zwalnia jednak od konieczności rozważenia skutków prawnych stosowania tej instytucji na współczesnym rynku pracy. Brak ogólnej regulacji prawnej omawianej instytucji powoduje bowiem określone implikacje, w postaci wątpliwości przy jej stosowaniu czy w rażących przypadkach prowadzi do jej nadużywania. Należy zatem rozważyć w szczególności takie zagadnienia, jak zgodność owej instytucji z naturą stosunku pracy czy zasadami prawa pracy, ewentualne przesłanki dopuszczalności jej stosowania oraz charakter i skutki prawne zwolnienia pracownika $\mathrm{z}$ obowiązku świadczenia pracy $\mathrm{w}$ okresie wypowiedzenia.

Nawiązując stosunek pracy, zarówno pracodawca, jak i pracownik przyjmują na siebie zobowiązania, które są zobligowani wypełniać aż do momentu zakończenia tego stosunku. W świetle art. $22 \S 1$ k.p. obowiązkiem pracownika jest wykonywanie pracy określonego rodzaju na rzecz pracodawcy i pod jego kierownictwem oraz $\mathrm{w}$ miejscu i czasie wyznaczonym przez pracodawcę. Podstawowym obowiązkiem pracodawcy jest zaś zatrudnianie pracownika za wynagrodzeniem, przez co należy rozumieć nie tylko formalne istnienie stosunku pracy, lecz także w sensie materialnym - umożliwienie pracownikowi faktycznego świadczenia umówionej pracy ${ }^{4}$. Świadczenie przez pracownika pracy w sposób ciągły, powtarzający się stanowi zatem istotę stosunku pracy. Pierwowzorem dzisiejszej umowy o pracę była umowa najmu usług wolnych

${ }^{1}$ Ustawa z 26 czerwca 1974 r. - Kodeks pracy, tekst jedn.: Dz. U. 1998, Nr 21, poz. 94 z późn. zm. (dalej jako: k.p.).

${ }^{2}$ Dz. U. 2008, Nr 227, poz. 1505.

${ }^{3}$ Wniosek ten znajduje również potwierdzenie w judykaturze, albowiem w wyroku z 4 marca 2009 r. Sąd Najwyższy (II PK 202/08) stwierdził, że pracodawca nie może według własnego, jednostronnego i swobodnego uznania zwolnić pracownika z obowiązku pracy (z zachowaniem prawa do wynagrodzenia), ponieważ $\mathrm{w}$ przepisach prawa pracy nie ma do tego podstawy prawnej (z wyjątkiem ustawowego zwolnienia $\mathrm{z}$ obowiązku świadczenia pracy w okresie wypowiedzenia pracownika odwołanego ze stanowiska, określonego w art. $70 \S 2$ k.p.).

${ }^{4}$ Zob. wyrok Sądu Najwyższego z 28 października 1998 r., I PKN 361/98, OSNPiUS 1999, Nr 23, poz. 750 oraz poglądy doktryny, m.in. W. Szubert, Zarys prawa pracy, Warszawa 1976, s. 199-200; A. Kijowski, Obowiazek zatrudniania pracownika w stosunku pracy, „Państwo i Prawo” 1978, z. 3, s. $101 \mathrm{i} \mathrm{n.}$ 
ludzi (locatio conductio operarum), którzy oddawali do dyspozycji pracodawcy własną siłę robocza, przyrzekając świadczyć dlań pracę w zamian za wynagrodzenie $^{5}$. U podstaw wykształcenia się tego stosunku stał zamiar i potrzeba wykorzystania cudzej pracy do osiągnięcia określonych celów. Z biegiem czasu baczniejszą uwagę poświęcono pracownikowi jako podmiotowi stosunku pracy, czego najdobitniejszą oznaką jest hasło Międzynarodowej Organizacji Pracy „,praca nie jest towarem”. Dostrzeżono, że stosunek pracy to nie tylko stosunek prawny, na mocy którego dochodzi do swoistej wymiany dóbr (pieniędzy i siły roboczej) pomiędzy pracodawca a pracownikiem, ale powodujący również społecznie doniosłe skutki. Praca jest jedną z najwyżej cenionych i pożądanych wartości. Stanowi obecnie podstawowe źródło zarobkowania człowieka. Przez pracę człowiek kształtuje swoją osobowość, uczy się oraz wypełnia jedną z najważniejszych w życiu ról społecznych. Stąd też wykonywanie przez pracownika pracy na rzecz pracodawcy i pod jego kierownictwem jest nie tylko obowiązkiem, ale również uprawnieniem pracownika. Stosunek pracy ze swojej istoty oparty jest na zasadzie wzajemności (ekwiwalentności), w myśl której świadczenie jednej ze stron jest odpowiednikiem świadczenia drugiej strony. Z powyższych względów zwolnienie pracownika z obowiązku świadczenia pracy $\mathrm{w}$ okresie wypowiedzenia należy uznać za pozostające zasadniczo $\mathrm{w}$ sprzeczności z naturą stosunku pracy i jego społeczno-gospodarczym przeznaczeniem.

II. Dokonując oceny omawianej instytucji z punktu widzenia jej zgodności $\mathrm{z}$ podstawowymi zasadami prawa pracy, należy zwrócić uwage przede wszystkim na zasadę prawa do pracy oraz zasadę równego traktowania i niedyskryminacji. Zgodnie $\mathrm{z}$ wyrażoną $\mathrm{w}$ art. $10 \S 1 \mathrm{k} . \mathrm{p}$. zasadą prawa do pracy każdy ma prawo do swobodnie wybranej pracy [...], państwo zaś prowadzi politykę zmierzającą do pełnego produktywnego zatrudnienia (art. $10 \S 3$ k.p.). $\mathrm{Z}$ zasady tej, analizowanej z punktu widzenia istoty stosunku pracy, wynika nie tyle prawo pracownika do pracy w sensie formalnym (formalnego zatrudnienia), ile przede wszystkim prawo do pracy rzeczywiście świadczonej (rzeczywiste zatrudnienie). Tylko bowiem taki sposób pojmowania tej zasady pozwala na określenie zatrudnienia mianem produktywnego w rozumieniu art. $10 \S 3$ k.p., czyli umożliwiającego pełne wykorzystanie czasu pracy i kwalifikacji pracownika w zamian za wynagrodzenia za pracę faktycznie przez niego wykonana ${ }^{6}$. Prawo pracownika do pracy faktycznie świadczonej powinno być zatem realizowane również $\mathrm{w}$ okresie wypowiedzenia. Warte przytoczenia $\mathrm{w}$ powyższej kwestii jest orzecznictwo sądów angielskich, które wielokrotnie zajmowały się relacją pomiędzy instytucją zwolnienia pracownika z obowiązku świadczenia pracy $\mathrm{w}$ okresie wypowiedzenia (określaną mianem garden leave) a prawem pracownika do pracy (the right to work). W orzeczeniu z 2 kwietnia $1998 \mathrm{r}$. wydanym w sprawie William Hill Organisation Ltd v. Tucker ${ }^{7}$ sąd apelacyjny

\footnotetext{
${ }^{5}$ T. Zieliński, Prawo pracy Zarys systemu. Część I. Ogólna, Warszawa-Kraków 1986, s. 67.

${ }^{6} \mathrm{Na}$ powiązanie obowiązku faktycznego zatrudniania pracownika z zasadą prawa do pracy zwrócił uwage A. Kijowski, op. cit., s. 104.

${ }^{7}$ [1998] England and Wales Court of Appeal Civil Division, syg. EWCA Civ615, http://www.bailii. org/ew/cases/EWCA/Civ/1998/615.html (8.04.2011).
} 
zwrócił uwagę na interesujący aspekt rozpatrywanego problemu, albowiem przyjął, że przy ocenie możliwości odsunięcia pracownika od pracy w okresie wypowiedzenia istotne znaczenie ma rodzaj pracy lub stanowisko zajmowane przez danego pracownika oraz jego kwalifikacje zawodowe. Sąd ten stwierdził w konkluzji, że w sytuacji gdy takowe odsunięcie wywarłoby negatywny wpływ na poziom wiedzy i umiejętności pracownika, doprowadzając do ich stopniowego zaniku, takiemu pracownikowi przysługuje prawo do pracy również $\mathrm{w}$ okresie wypowiedzenia.

Zwolnienie pracownika $\mathrm{z}$ obowiązku świadczenia pracy może również nie czynić zadość zasadzie równego traktowania pracowników oraz zasadzie niedyskryminacji. Skoro pracownicy powinni być równo traktowani w zakresie nawiazzania i rozwiązania stosunku pracy, to tym bardziej zasada ta winna obowiązywać w zakresie dopuszczenia pracownika do faktycznego świadczenia pracy $\mathrm{w}$ czasie trwania tego stosunku. Decyzja pracodawcy o zwolnieniu pracownika z obowiązku świadczenia pracy w okresie wypowiedzenia związana tylko z samym faktem złożenia przez pracownika wypowiedzenia albo wypowiedzeniem mu umowy o pracę przez pracodawcę, może stanowić również przejaw dyskryminacji pracownika. Pogląd ten znajduje odzwierciedlenie w orzecznictwie, w którym przyjęto, że bezpodstawne odsunięcie pracownika od wykonywania pracy $\mathrm{w}$ okresie wypowiedzenia noszące znamiona szykany pozostaje w sprzeczności z prawem ${ }^{8}$.

Mając na uwadze, że na pracodawcy zgodnie z art. 22 k.p. ciąży obowiązek (faktycznego) zatrudniania pracownika formułuje się na tej podstawie w literaturze tak zwaną zasadę realnego zatrudnienia ${ }^{9}$. Zwolnienie pracownika $\mathrm{z}$ obowiązku świadczenia pracy $\mathrm{w}$ okresie wypowiedzenia może godzić $\mathrm{w}$ tak pojmowana zasadę realnego zatrudnienia, albowiem uniemożliwia pracownikowi w tym okresie rzeczywiste wykonywanie pracy, pozostawiając mu jednakże status ,formalnie” zatrudnionego. Jakkolwiek pracy człowieka przypisać należy w pierwszej kolejności cel zarobkowy, nie można jednak pomijać innych jej aspektów, o wymiarze socjologicznym, psychologicznym czy etycznym. Praca jest współcześnie dla człowieka jednym z najwyżej cenionych i pożądanych dóbr. W pracy człowiek rozwija się, wykorzystuje i podnosi jednocześnie swoje kwalifikacje zawodowe, w pracy zespołowej uczy się również współegzystować z innymi ludźmi. Podnosi się zatem, że praca człowieka, w tym szczególnie jego praca zawodowa, jest wartością trwałą i uniwersalna zarazem ${ }^{10}$. W związku z tym, w mojej ocenie, prawo pracownika do faktycznego wykonywania pracy powinno być zapewniane tak dalece, jak jest to tylko możliwe, ponieważ tylko $\mathrm{w}$ ten sposób zasada realnego zatrudnienia jest realizowana najpełniej, w maksymalnym stopniu, a stosunek pracy spełnia swoje społeczno-gospodarcze przeznaczenie. Poza tym wychodząc naprzeciw

${ }^{8}$ Zob. uzasadnienie wyroku Sądu Najwyższego z 28 października 1998 r., I PKN 361/98, OSNPiUS 1999, Nr 23, poz. 750.

${ }^{9}$ Szerzej w tej kwestii zob. M. Raczkowski, Zwolnienie z obowiazku świadczenia pracy a zasada realnego zatrudnienia, „Praca i Zabezpieczenie Społeczne” 2008, nr 3, s. 25 i n.

10 Z. Wiatrowski, Praca $w$ zbiorach wartości pracujacych, bezrobotnych $i$ mtodzieży szkolnej, Włocławek 2004, s. 177. 
postulatom uelastycznienia prawa pracy oraz potrzebie zapewnienia skutecznej ochrony interesów pracodawcy, w pewnych wyjątkowych sytuacjach, należy jednak dopuścić możliwość zwolnienia pracownika z obowiązku świadczenia pracy w okresie wypowiedzenia.

III. Uznając zwolnienie pracownika $\mathrm{z}$ obowiązku świadczenia pracy w okresie wypowiedzenia za wyjątkowo dopuszczalne, należy przede wszystkim określić przesłanki dopuszczalności takiego zwolnienia. W doktrynie niekiedy uznaje się za taka przesłankę nieuchronność rozwiązania stosunku pracy, argumentując, że skoro nie ma perspektywy ciagłości zatrudnienia, maleje znaczenie zasady realnego zatrudnienia ${ }^{11}$. Moim zdaniem jednak wypowiedzenie umowy o pracę per se nie stanowi uzasadnionej podstawy do odsunięcia pracownika od faktycznego świadczenia pracy. Odmowa dopuszczenia pracownika do pracy w okresie wypowiedzenia wyłącznie z powodu wypowiedzenia mu umowy o pracę przez pracodawcą albo złożenia takiego wypowiedzenia przez pracownika pozostaje bowiem zasadniczo $\mathrm{w}$ sprzeczności $\mathrm{z}$ istotą stosunku pracy, zasadą prawa do pracy oraz zasadą równego traktowania pracowników i zasada niedyskryminacji. Okres wypowiedzenia stosunku pracy nadal pozostaje czasem ,zwykłego" wykonywania przez strony tego stosunku swoich obowiązków. Pracownik zobowiązany jest w tym okresie do wykonywania pracy na rzecz i pod kierownictwem pracodawcy, a pracodawca - do faktycznego zatrudniania pracownika oraz zapłaty mu umówionego wynagrodzenia. Warto jednak zwrócić uwagę, że okres wypowiedzenia stosunku pracy, dokonanego przez którąkolwiek z jego stron, jest czasem szczególnym zarówno dla pracodawcy, jak i pracownika. Świadomość w zasadzie nieuchronności zakończenia stosunku pracy, poprzedzona zazwyczaj zaskoczeniem związanym $\mathrm{z}$ dokonanym wypowiedzeniem, powoduje, że pracownik w pewnym sensie staje się osobą niechcianą czy niepożądaną w firmie. Z jednej strony pracodawca może się obawiać, że pracownik w okresie wypowiedzenia nie będzie wykonywał pracy w sposób sumienny i staranny czy w skrajnych przypadkach będzie nawet próbował działać na niekorzyść pracodawcy (na przykład gromadząc informacje stanowiące tajemnice przedsiębiorstwa). Z drugiej strony pracodawcy może zależeć na jak najszybszym zapełnieniu przyszłego wakatu i wdrożeniu nowego pracownika w obowiązki odchodzącego pracownika. Jeżeli zatem „niechciany” pracownik nie zgodzi się na zawarcie porozumienia w przedmiocie rozwiązania stosunku pracy - co zazwyczaj wiązać się będzie z utrata wynagrodzenia za okres wypowiedzenia - to jedynym sposobem pracodawcy na natychmiastowe odsunięcie pracownika od pracy jest dokonanie wypowiedzenia i jednoczesne zwolnienie go z obowiązku świadczenia pracy w okresie wypowiedzenia. Przy czym podkreśla się, że okoliczność ta dotyczy przede wszystkim kadry zarządzającej, w tym członków zarządu spółek prawa handlowego ${ }^{12}$.

\footnotetext{
11 Tak: M. Raczkowski, op. cit., s. 27.

${ }^{12}$ M. Gersdorf, Zwolnienie pracownika z obowiazku świadczenia pracy, „Praca i Zabezpieczenie Społeczne" 2005, nr 3, s. 31.
} 
$\mathrm{W}$ istocie zatem odsunięcie pracownika od świadczenia pracy w okresie wypowiedzenia powinno być dopuszczalne w sytuacji, gdy rzeczywiste wykonywanie przez niego pracy w tym okresie jest co najmniej niecelowe i narusza (bądź zagraża naruszeniem) słuszne interesy pracodawcy, przy czym wydaje się, że stopień zagrożenia tych interesów powinien być znaczny. Samo nienależyte wykonywanie obowiązków pracowniczych tylko w wyjątkowych przypadkach powinno prowadzić do odsunięcia pracownika od pracy w okresie wypowiedzenia. Zwolnienie pracownika $\mathrm{z}$ obowiązu świadczenia pracy $\mathrm{w}$ okresie wypowiedzenia powinno, w moim przekonaniu, pełnić funkcję ochronna wobec pracodawcy, a nie powinno stać się zwyczajem. Pogląd powyższy znajduje potwierdzenie $\mathrm{w}$ orzecznictwie, zgodnie $\mathrm{z}$ którym jednostronne zwolnienie pracownika przez pracodawcę $\mathrm{z}$ obowiązku świadczenia pracy jest możliwe tylko ze względu na jego dobro i z poszanowaniem słusznych interesów pracownika oraz przy uznaniu tego za oczywisty wyjątek od zasady, że wynagrodzenie przysługuje tylko za pracę wykonaną ${ }^{13}$.

Jeżeli nie zostaną spełnione wyżej określone przesłanki do zwolnienia pracownika $\mathrm{z}$ obowiązku świadczenia pracy w okresie wypowiedzenia, pracodawca będzie zobligowany do faktycznego umożliwienia pracownikowi wykonywania pracy do chwili rozwiązania stosunku pracy. W razie bezprawnego niedopełnienia przez pracodawcę obowiązku zatrudniania $\mathrm{w}$ okresie wypowiedzenia pracownikowi będzie przysługiwać roszczenie o dopuszczenie do pracy na podstawie art. $22 \S 1$ k.p. ${ }^{14}$ Zasadność powyższego roszczenia będzie uzależniona przede wszystkim od stwierdzenia bezprawności postępowania pracodawcy.

Zgodnie ze stanowiskiem doktryny do okoliczności wyłączających bezprawność niezatrudniania pracownika zaliczyć trzeba te, które uniemożliwiaja ,,danie” pracy (z wyjątkiem zawinionych przez zatrudniającego), jak i okoliczności, które nie powodując takiej niemożliwości, przesądzają o chwilowej niecelowości zatrudniania z punktu widzenia przeważającego interesu zakładu i wykazują tym samym pewne podobieństwo do stanu wyższej konieczności ${ }^{15}$. Należy jednak stwierdzić, że sam wzgląd na dobro pracodawcy czy potrzebę ochrony jego interesów nie uzasadnia każdorazowo odsunięcia pracownika od pracy w okresie wypowiedzenia. Oznacza to, że w okolicznościach faktycznych konkretnej sprawy sąd może przyznać prymat słusznym interesom pracownika i orzec o obowiązku pracodawcy dopuszczenia pracownika do rzeczywistego wykonywania pracy $\mathrm{w}$ okresie wypowiedzenia. $\mathrm{W}$ tym kontekście interesujący wydaje się przywołany wcześniej wyrok w sprawie

${ }^{13}$ Z uzasadnienia wyroku Sądu Najwyższego z 24 września 2003 r., I PK 324/02, OSNP 2004, nr 18, poz. 313.

${ }^{14}$ Zob. wyrok Sądu Najwyższego z 4 marca 2009 r., II PK 202/08, w którym Sąd ten stwierdził, że wzajemny obowiązek pracodawcy zatrudniania pracownika za wynagrodzeniem przysługującym za prace wykonaną sprzeciwia się odsunięciu przez pracodawcę od świadczenia pracy pracownika, któremu w przypadkach bezpodstawnego lub bezprawnego zwolnienia z obowiązku świadczenia pracy w okresie trwającego stosunku pracy - przysługuje roszczenie o dopuszczenie do świadczenia umówionej lub innej odpowiedniej pracy.

15 A. Kijowski, Pracowniczy obowiazek gotowości do świadczenia pracy, Poznań 1978, s. 37-38. 
William Hill Organisation Ltd $v$. Tucker, z którego wynika, że oceniając prawa pracownika do faktycznego wykonywania pracy, należy brać pod uwagę rodzaj wykonywanej przez niego pracy i posiadane kwalifikacje zawodowe. Można w związku z tym postawić tezę, że w wypadku zawodów twórczych oraz wymagających nieustannego doskonalenia się czy podatnych na częste zmiany odsunięcie pracownika od ich wykonywania wywołuje dla niego szczególnie ujemne skutki i należy rozważyć potrzebę przedłożenia jego słusznego interesu nad interes pracodawcy ${ }^{16}$. Uważam, że podobnie należy podejść do sytuacji, w której faktyczne wykonywanie przez pracownika pracy (zawodu) ma bezpośredni wpływ na jego uprawnienia zawodowe czy poziom umiejętności (na przykład w zawodzie lekarza). Należy jednak podkreślić, że nawet jeśli pracownik zwolniony z obowiązku świadczenia pracy w okresie wypowiedzenia wystapi przeciwko pracodawcy $\mathrm{z}$ roszczeniem o dopuszczenie do pracy na podstawie art. 22 k.p., ze względów pragmatycznych (upływ okresu wypowiedzenia oraz długotrwałość postępowania sądowego) wydanie orzeczenia $\mathrm{w}$ sprawie najczęściej nastąpi już po rozwiązaniu stosunku pracy. W związku $\mathrm{z}$ tym $\mathrm{w}$ istocie pracownikowi przysługiwać będzie tylko roszczenie o odszkodowanie. Zgodnie z rozkładem ciężaru dowodu to pracownik będzie musiał jednak udowodnić fakt powstania szkody oraz związek przyczynowy między szkoda a niedopełnieniem przez pracodawca obowiązku jego zatrudniania w okresie wypowiedzenia.

IV. Zwolnienie pracownika $\mathrm{z}$ obowiązku świadczenia pracy $\mathrm{w}$ okresie wypowiedzenia, zgodnie $\mathrm{z}$ art. 60 k.c. ${ }^{17}$ stosowanego odpowiednio w oparciu o art. 300 k.p., może nastąpić w dowolnej formie. Dla celów dowodowych pożadane jest jednak dokonanie powyższej czynności na piśmie. Przy zawieraniu umowy o pracę dopuszczalne jest również zamieszczenie w umowie przez jej strony stosownej klauzuli, przewidującej możliwość zwolnienia pracownika $\mathrm{z}$ obowiązku świadczenia pracy $\mathrm{w}$ okresie wypowiedzenia z zachowaniem prawa do wynagrodzenia. Klauzula ta występuje między innymi w prawie anglosaskim, w którym znana jest pod nazwa garden leave clause. Zamieszczenie $\mathrm{w}$ umowie o pracę postanowienia o możliwości zwolnienia pracownika $\mathrm{z}$ obowiązku świadczenia pracy w okresie wypowiedzenia w praktyce pozwala zabezpieczyć interesy pracodawcy i uniknąć wątpliwości związanych z korzystaniem $\mathrm{z}$ tej instytucji prawnej.

Wciąż aktualne pozostaje jednak pytanie, czy wobec braku stosownej klauzuli umownej oraz porozumienia między stronami stosunku pracy zwolnienie pracownika $\mathrm{z}$ obowiązku świadczenia pracy $\mathrm{w}$ okresie wypowiedzenia może zostać dokonane w formie jednostronnego oświadczenia woli pracodawcy, skoro rzeczywiste wykonywanie przez pracownika uzgodnionej pracy jest elementem definicyjnym stosunku pracy. W istocie jest to również pytanie

\footnotetext{
${ }^{16} \mathrm{Na}$ aspekt ten słusznie zwróciła uwagę M. Gersdorf, op. cit., s. 31, stwierdzając, że ,,problem z pewnością nasili się w stosunku do pracowników wykonujących pracę twórczą, których pozbawienie warsztatu pracy (mikrofonu, ekranu) może być bardziej dotkliwe. Pozbawia bowiem publiczności, sławy, niwecząc dorobek życia, tj. fakt uznania za osobę powszechnie znaną".

${ }^{17}$ Ustawa z 23 kwietnia 1964 r. - Kodeks cywilny, Dz. U. Nr 16, poz. 93 z późn. zm.
} 
o zasięg kierownictwa pracodawcy w łączącym go $\mathrm{z}$ pracownikiem stosunku prawnym. Stosownie do art. $100 \S 1$ k.p. pracownik zobligowany jest do stosowania się do poleceń przełożonych dotyczących pracy. Odsunięcia pracownika od wykonywania pracy w okresie wypowiedzenia nie można jednak moim zdaniem - zakwalifikować jako polecenia dotyczącego pracy, lecz jako ukształtowania „,nowej” sytuacji prawnej zarówno pracownika (zwolnienia go od obowiązku świadczenia pracy), jak i samego pracodawcy (zwolnienia z obowiązku zatrudniania pracownika). W konsekwencji należy uznać, że jednostronne odsunięcie przez pracodawcę pracownika od świadczenia pracy w okresie wypowiedzenia powinno być dopuszczalne tylko ze względu na dobro pracodawcy i w celu ochrony jego interesów przy jednoczesnym poszanowaniu słusznych interesów pracownika. Wartością podlegająca w tym przypadku ochronie jest dobro zakładu pracy, pojmowane jako niezakłócone funkcjonowanie tego zakładu czy zminimalizowanie zagrożenia naruszenia przez ,odchodzącego” pracownika interesów pracodawcy, pośrednio zaś również interesów pozostałych pracowników zatrudnionych w tym zakładzie. De lege lata w Kodeksie pracy brak jest podstawy prawnej do jednostronnego zwolnienia pracownika $\mathrm{z}$ obowiazku świadczenia pracy $\mathrm{w}$ okresie wypowiedzenia. W moim przekonaniu, takiej podstawy nie stanowi art. $100 \S 1$ pkt 4 k.p., statuujący obowiązek dbałości pracownika o dobro zakładu pracy (pracodawcy). Trudno bowiem przyjąc $\mathrm{w}$ mojej ocenie, by realizacja przez pracownika tego obowiązku mogła polegać na rezygnacji przez niego z uprawnienia do faktycznego świadczenia pracy (art. $22 \S 1$ k.p.), godziłoby to bowiem w sama naturę stosunku pracy. Ze względu na powyższe zasadne jest sformułowanie wniosku de lege ferenda $\mathrm{w}$ przedmiocie dokonania prawnej regulacji instytucji zwolnienia pracownika $\mathrm{z}$ obowiązku świadczenia pracy $\mathrm{w}$ okresie wypowiedzenia.

V. Skutkiem dokonanego przez pracodawcę zwolnienia pracownika z obowiazku świadczenia pracy w okresie wypowiedzenia jest zawieszenie pracowniczego obowiązku świadczenia pracy oraz skorelowanego z nim obowiązku pracodawcy faktycznego zatrudniania pracownika. Stosunek pracy pomiędzy jego stronami formalnie trawa nadal aż do upływu okresu wypowiedzenia, nie ustaje również obowiązek pracodawcy wypłaty pracownikowi wynagrodzenia, mimo niewykonywania przez niego pracy. Wysokość wynagrodzenia wypłacanego pracownikowi za czas jego zwolnienia z obowiązku świadczenia pracy jest kwestią budzącą poważne wątpliwości w praktyce stosowania tej instytucji prawnej. Najpowszechniejsze są dwa ujęcia tego zagadnienia. W świetle pierwszego, dyktowanego zwłaszcza względami pragmatycznymi oraz chęcia uniknięcia konfliktu z pracownikiem, pracodawca wypłaca pracownikowi zwolnionemu z obowiązku świadczenia pracy wynagrodzenie jak za urlop wypoczynkowy $^{18}$ na mocy odesłania zawartego $\mathrm{w}$ rozporządzeniu $\mathrm{w}$ sprawie między

\footnotetext{
${ }^{18}$ Zob. rozporządzenie Ministra Pracy i Polityki Socjalnej z 8 stycznia $1997 \mathrm{r}$. w sprawie szczegółowych zasad udzielania urlopu wypoczynkowego, ustalania i wypłacania wynagrodzenia za czas urlopu oraz ekwiwalentu pieniężnego za urlop, Dz. U. 1997, Nr 2, poz. 14 ze zm.
} 
innymi sposobu ustalania wynagrodzenia w okresie niewykonywania pracy ${ }^{19}$. Zgodnie $\mathrm{z}$ drugim stanowiskiem $\mathrm{w}$ takim przypadku znajduje zastosowanie art. $81 \S 1$ k.p., ponieważ pracownik zwolniony z obowiązku świadczenia pracy oznaje przeszkód $\mathrm{w}$ jej wykonywaniu $\mathrm{z}$ przyczyn dotyczących pracodawcy i z tego tytułu przysługuje mu wynagrodzenie w wysokości określonej w tym przepisie, jest to tak zwane wynagrodzenie przestojowe ${ }^{20}$.

Nasuwa się jednak refleksja, że ratio legis przepisu art. 81 k.p. nie oddaje istoty oraz celu instytucji zwolnienia pracownika $\mathrm{z}$ obowiązku świadczenia pracy $\mathrm{w}$ okresie wypowiedzenia. W pierwszej kolejności należy wskazać, że przepis ten pełni funkcję ochronną względem pracownika i zapewnia wypłatę tak zwanego wynagrodzenia gwarancyjnego za czas niewykonywania pracy w sytuacji, gdy był on gotów do jej wykonywania, a doznał przeszkód z przyczyn dotyczących pracodawcy. Tymczasem prawo pracodawcy do zwolnienia pracownika $\mathrm{z}$ obowiązku świadczenia pracy $\mathrm{w}$ okresie wypowiedzenia jest instytucją służącą głównie ochronie interesów pracodawcy. Istotne jest również to, że $\mathrm{w}$ sytuacji zwolnienia pracownika $\mathrm{z}$ obowiązku świadczenia pracy, poprzedzonego wypowiedzeniem przez pracodawcę stosunku pracy, gotowość pracownika do wykonywania pracy, o której mowa w art. $81 \S 1$ k.p., może ulec, w mniejszym czy większym stopniu, osłabieniu. Sama wola pracodawcy nie uzasadnia odsunięcia pracownika od pracy $\mathrm{w}$ okresie wypowiedzenia, nieodzowne jest również wystąpienie przesłanki ochrony słusznych interesów pracodawcy. W zwiazku z tym, w mojej ocenie, instytucja zwolnienia pracownika $\mathrm{z}$ obowiązku świadczenia pracy $\mathrm{w}$ okresie wypowiedzenia nie powinna znajdować się w zakresie zastosowania art. 81 k.p. Należy w szczególności rozważyć, czy nie jest uzasadnione zapewnienie pracownikowi w tym okresie pełnego wynagrodzenia za pracę ${ }^{21}$. Warto zaznaczyć, że zachowanie przez pracownika prawa do wynagrodzenia za czas jego zwolnienia $\mathrm{z}$ obowiązku świadczenia pracy $\mathrm{w}$ okresie wypowiedzenia zostało przewidziane przez Komisję Kodyfikacyjną Prawa Pracy w projekcie indywidualnego Kodeksu pracy z kwietnia $2008 \mathrm{r}^{22} \mathrm{Za}$ takim rozwiązaniem przemawiaja trzy istotne

19 Zob. rozporządzenie Ministra Pracy i Polityki Socjalnej z 29 maja 1996 r. w sprawie sposobu ustalania wynagrodzenia w okresie niewykonywania pracy oraz wynagrodzenia stanowiącego podstawę odszkodowań, odpraw, dodatków wyrównawczych do wynagrodzenia oraz innych należności przewidzianych w Kodeksie pracy, Dz. U. 1996, Nr 62, poz. 289 ze zm.

${ }^{20} \mathrm{Ku}$ takiej wykładni skłania się M. Gersdorf, op. cit., s. 32 a także Sąd Najwyższy m.in. w wyroku z 16 czerwca 2005 r., I PK 260/04, OSNP 2006, nr 9-10, poz. 145 i wcześniej w wyroku z 16 listopada 2000 r., I PKN 455/00, OSNAPiUS 2002, nr 11, poz. 268.

${ }^{21}$ Za takim rozwiązaniem, moim zdaniem trafnie, opowiada się Kazimierz Jaśkowski, stwierdzając, że ,,względy słuszności i sprawiedliwości przemawiają za nieobciążaniem pracownika ryzykiem utraty choćby części wynagrodzenia w razie niewykonywania pracy z powodu celowego odsunięcia go przez pracodawcę od jej wykonywania wyłącznie dla ochrony własnych interesów majątkowych”; idem, Zawieszenie obowiazku wykonywania pracy w umownym stosunku pracy, w: Z. Niedbała (red.), Księga Pamiatkowa w Piata Rocznice śmierci Profesora Andrzeja Kijowskiego, Warszawa 2010, s. 85.

${ }^{22}$ Zob. art. 86 § 3 Projektu indywidualnego Kodeksu pracy (kwiecień 2008 r.), udostępnionego na stronie internetowej Ministerstwa Pracy i Polityki Socjalnej: http://www.mpips.gov.pl/index.php? gid $=1250$, zgodnie z którym ,w okresie wypowiedzenia pracodawca może zwolnić pracownika z obowiązku świadczenia pracy z zachowaniem prawa do wynagrodzenia za czas tego zwolnienia" oraz art. 86 $\S 4$, w myśl którego ,,czas zwolnienia pracownika z obowiązku świadczenia pracy obejmuje cały okres wypowiedzenia, jeżeli pracodawca nie określił go odmienne”. 
argumenty. Po pierwsze - zwolnienie pracownika z obowiązku świadczenia pracy w okresie wypowiedzenia jest instytucją chroniąca przede wszystkim interesy pracodawcy. Po drugie - uniemożliwienie pracownikowi faktycznego wykonywania pracy, która posiada nie tylko wymiar ekonomiczny, w powiązaniu, co do zasady, $\mathrm{z}$ nieuchronnością rozwiązania stosunku pracy i zazwyczaj utratą przez pracownika źródła dochodu przemawia za wypłatą mu pełnego wynagrodzenia za pracę. Po trzecie - konieczność wypłaty pracownikowi za okres wypowiedzenia wynagrodzenia w pełnej wysokości bez uzyskania $\mathrm{z}$ jego strony świadczenia wzajemnego stanowić będzie swoisty mechanizm ochronny przed nadmiernym wykorzystywaniem przez pracodawców instytucji zwolnienia pracownika $\mathrm{z}$ obowiązku świadczenia pracy w okresie wypowiedzenia. Zwolnienie to bowiem godzi w samą naturę stosunku pracy i powinno być wyjątkiem od zasady, a nie stać się zasadą. Celowe jest zatem sformułowanie postulatu de lege ferenda, aby jednoznacznie uregulować kwestię wynagrodzenia przysługującego pracownikowi w czasie zwolnienia pracownika z obowiązku świadczenia pracy w okresie wypowiedzenia. W myśl bowiem art. 80 zd. 2 k.p. za czas niewykonywania pracy pracownik zachowuje prawo do wynagrodzenia tylko wówczas, gdy przepisy prawa tak stanowią.

VI. Pracownik zwolniony $\mathrm{z}$ obowiązku świadczenia pracy w okresie wypowiedzenia, pomimo faktycznego zawieszenia jego obowiązku wykonywania umówionej pracy, nie traci statusu pracownika. Formalna więź między stronami stosunku pracy istnieje bowiem aż do momentu rozwiązania tego stosunku (w omawianym przypadku - upływu okresu wypowiedzenia). Rozważenia wymaga jednak kwestia praw i obowiązków pracownika zwolnionego z obowiązku świadczenia pracy. Podstawowym prawem pracownika odsuniętego od wykonywania pracy w okresie wypowiedzenia jest prawo do wynagrodzenia za pracę (w istocie nieświadczoną). Regulacja ta jest zatem wyjątkiem od zasady określonej w art. 80 k.p., zgodnie z którym wynagrodzenie przysługuje za pracę wykonaną. Okres zwolnienia pracownika od obowiązku świadczenia pracy wlicza się do okresu pracy, od którego zależą uprawnienia pracownicze. Oznacza to, że w czasie faktycznego niewykonywania pracy pracownik w szczególności nabywa prawo do urlopu wypoczynkowego czy nagród jubileuszowych lub prawo do nieodpłatnego nabycia akcji komercjalizowanego przedsiębiorstwa państwowego.

W związku z uchyleniem obowiązku faktycznego zatrudniania pracownika $\mathrm{w}$ okresie wypowiedzenia pracodawca jest zwolniony wobec pracownika z poszczególnych obowiązków związanych bezpośrednio z wykonywaniem przez niego pracy. Ze względu na cel instytucji zwolnienia pracownika z obowiązku świadczenia pracy w okresie wypowiedzenia zasadny wydaje się pogląd o pozbawieniu w tym czasie pracownika prawa dostępu do miejsca (stanowiska) wykonywania pracy, nie należy tego jednak - moim zdaniem - utożsamiać z bezwzględnym zakazem wstępu na teren zakładu pracy, o ile przemawia za tym uzasadniony interes pracownika i następuje to za zgodą bądź wiedza pracodawcy. Pracownik zwolniony z obowiązku świadczenia pracy jest zobowiązany do udzielania pracodawcy wszelkich wyjaśnień czy informacji zwią- 
zanych z wykonywaną przez niego dotychczas praca czy pełnionym stanowiskiem. W okresie biegnącego wypowiedzenia na pracowniku ciąży także szereg obowiązków, w tym w szczególności obowiązek dbałości o dobro zakładu pracy (art. $100 \S 2$ pkt 4 k.p.). Obowiązek ten jednak nie stoi na przeszkodzie temu, by pracownik w okresie tego zwolnienia podjął inną pracę bądź działalność gospodarczą, o ile jednak praca ta lub działalność nie mają charakteru konkurencyjnego wobec działalności dotychczasowego pracodawcy ${ }^{23}$. Uchybienie wskazanym obowiązkom, zwłaszcza uporczywe uchylanie się pracownika od udzielania pracodawcy potrzebnych informacji czy wyjaśnień (w rażącym przypadku - nieudostępnienie stosownych dokumentów, podjęcie pracy lub działalności konkurencyjnej czy wręcz umyślne wyrządzenie szkody pracodawcy) może zostać zakwalifikowane jako ciężkie naruszenie podstawowych obowiązków pracowniczych i uzasadniać rozwiązanie $\mathrm{z}$ tym pracownikiem stosunku pracy bez wypowiedzenia na mocy art. $52 \S 1$ pkt 1 k.p.

Kwestią wymagającą rozważenia jest również zakres dyspozycyjności pracownika zwolnionego $\mathrm{z}$ obowiązku świadczenia pracy $\mathrm{w}$ okresie wypowiedzenia. Zwolnienie to następuje bądź w postaci jednostronnego oświadczenia woli pracodawcy, bądź na mocy zgodnych oświadczeń woli stron stosunku pracy. We wcześniejszym orzecznictwie przyjmowano, że zarówno do decyzji pracodawcy w przedmiocie zwolnienia pracownika z obowiązku świadczenia pracy, jak i cofnięcia takiego zwolnienia stosuje się, w oparciu o art. $300 \mathrm{k} . p$., przepisy o oświadczeniach woli zawarte w Kodeksie cywilnym ${ }^{24}$. Zgodnie zaś z art. 61 $\S 1$ k.c. odwołanie oświadczenia woli jest skuteczne, jeśli doszło do adresata jednocześnie lub wcześniej. W przeciwnym wypadku do cofnięcia oświadczenia woli niezbędna jest zgoda jego adresata. Oznacza to, że skuteczne zwolnienie z obowiązku świadczenia pracy w okresie wypowiedzenia przesądza o tym, że pracownik, który nie wyraża zgody na cofnięcie oświadczenia woli w tej sprawie, nie musi podporządkować się poleceniom pracodawcy świadczenia pracy we wskazanym miejscu i terminie. Jeśli pracownik nie zastosuje się do takich poleceń, nie stanowi to ciężkiego naruszenia podstawowych obowiązków pracowniczych - art. $52 \S 1$ pkt 1 k.p. ${ }^{25}$ Przeciwne stanowisko zają Sąd Najwyższy w przywołanym wcześniej wyroku z 4 marca 2009 r.: ,jednostronne bezpodstawne zwolnienie pracownika z obowiązku wykonywania pracy w okresie trwającego stosunku pracy może być w każdym czasie odwołane przez pracodawcę poprzez wezwanie pracownika do podjęcia świadczenia pracy, a warunek uzyskania zgody pracownika na cofnięcie złożonego przez pracodawcę oświadczenia o zwolnieniu pracownika z obowiązku świadczenia pracy wedle art. $61 \S 1$ zdanie drugie k.c. powinien być postrzegany jako oczywiście sprzeczny z art. $22 \S 1 \mathrm{k}$.p. oraz podstawowa zasadą prawa pracy dotycząca godziwego wynagrodzenia pracownika za pracę (art. 13 zdanie pierwsze k.p.), która dotyczy przede wszystkim wynagrodzenia za pracę

${ }^{23}$ Zob. wyrok Sądu Najwyższego z 26 stycznia 2005 r., II PK 191/04.

${ }^{24}$ M.in. wyroki Sądu Najwyższego: z 6 października 1998 r., I PKN 369/98; z 18 listopada 1999 r., I PKN 375/99; z 20 czerwca 2001 r., I PKN 475/00 oraz wyrok Sądu Apelacyjnego w Warszawie z 21 czerwca 2005 r., III APa 48/05.

${ }^{25}$ Zob. wyrok Sądu Najwyższego z 5 lipca 2005 r., I PK 176/04, OSNP 2006, nr 9-10, poz. 154. 
wykonaną (art. 80 zdanie pierwsze k.p.), co sprzeciwiało się w rozpoznawanej sprawie dopuszczalności odpowiedniego stosowania art. $61 \S 1$ zdanie drugie k.c. z mocy art. 300 k.p." (II PK 202/08).

Odnosząc powyższe stanowiska Sądu Najwyższego zarówno do celu, jak i charakteru instytucji zwolnienia pracownika z obowiązku świadczenia pracy w okresie wypowiedzenia, uważam, że do odwołania czy cofnięcia takiego zwolnienia zasadne jest uzyskanie zgody pracownika. Nie można bowiem zapominać, że zwolnienie to następuje w szczególnym okresie, zmierzającym do nieuchronnego zakończenia stosunku pracy oraz dyktowane jest szczególną potrzeba - ochrony interesów pracodawcy. Przyznanie pracodawcy $\mathrm{w}$ istocie arbitralnego prawa do wezwania pracownika do świadczenia pracy w okresie wypowiedzenia stanowiłoby przejaw nieposzanowania słusznych interesów pracownika, jak również nie sprzyjałoby pewności sytuacji zawodowej i życiowej pracownika. Obowiązku powrotu pracownika do faktycznego świadczenia pracy $\mathrm{w}$ okresie wypowiedzenia nie można również $\mathrm{w}$ takiej sytuacji - moim zdaniem - wywieść z pracowniczego obowiązku dbałości o dobro zakładu pracy, skoro pracodawca, kierując się właśnie dobrem tego zakładu i potrzebą ochrony jego interesów, uprzednio zwolnił $\mathrm{w}$ tym okresie pracownika $\mathrm{z}$ obowiązku świadczenia pracy.

Warto zaznaczyć, że decydując się na zwolnienie pracownika z obowiązku świadczenia pracy w okresie wypowiedzenia, pracodawca powinien gruntownie rozważyć skutki prawne tego zwolnienia, zważywszy na fakt, że w stosunku do osób piastujących stanowiska kierownicze często stosuje się wydłużony okres wypowiedzenia. W celu uniknięcia ewentualnych sporów za dopuszczalne i celowe zarazem należy uznać zamieszczenie $\mathrm{w}$ umowie o pracę (bądź $\mathrm{w}$ późniejszym porozumieniu $\mathrm{w}$ przedmiocie zwolnienia pracownika $\mathrm{z}$ obowiązku świadczenia pracy) klauzuli o możliwości odwołania tego zwolnienia. $\mathrm{W}$ istocie zatem uprawnienie pracodawcy w przedmiocie wezwania pracownika do świadczenia pracy w okresie wypowiedzenia powinno być uzależnione od przezorności pracodawcy i stopnia zabezpieczenia jego interesów, jako - co do zasady - silniejszej strony stosunku pracy. Odwołanie dokonanego zwolnienia może nastąpić w dowolnej formie, dla celów dowodowych pożądane jest jednak dokonanie tego na piśmie. Można również ograniczyć dopuszczalność odwołania zwolnienia pracownika $\mathrm{z}$ obowiązku świadczenia pracy $\mathrm{w}$ okresie wypowiedzenia do „szczególnych przypadków” czy „ważnych przyczyn”.

VII. Mając na uwadze powyższe rozważania, należy stwierdzić, że w związku z ukształtowaniem się praktyki zwalniania pracowników z obowiązku świadczenia pracy $\mathrm{w}$ okresie wypowiedzenia oraz wątpliwościami związanymi z jej stosowaniem, zasadne jest dokonanie kompleksowej regulacji prawnej omawianej instytucji w kodeksie pracy. Przedmiotem wskazanej regulacji powinno być przede wszystkim określenie przesłanki stosowania wskazanej instytucji, którą może stanowić zwłaszcza ochrona słusznych interesów pracodawcy. W takim wypadku należy rozważyć dopuszczenie zwolnienia pracownika $\mathrm{z}$ obowiązku świadczenia pracy $\mathrm{w}$ okresie wypowiedzenia, $\mathrm{z}$ zachowaniem prawa do wynagrodzenia, na mocy jednostronnego 
oświadczenia woli pracodawcy, którego odwołanie wymaga zasadniczo zgody pracownika. Zgodnie z autonomią woli stron, za dopuszczalne należy uznać również zamieszczenie $\mathrm{w}$ umowie o pracę stosownej klauzuli $\mathrm{w}$ przedmiocie zwolnienia pracownika $\mathrm{z}$ obowiązku świadczenia pracy $\mathrm{w}$ okresie wypowiedzenia (i ewentualnie jego odwołania). W przyszłości korzystanie $\mathrm{z}$ instytucji zwolnienia pracownika $\mathrm{z}$ obowiązku świadczenia pracy $\mathrm{w}$ okresie wypowiedzenia powinno, w mojej ocenie, mieć charakter wyjątkowy i zostać ograniczone do szczególnych przypadków, w których faktyczne zatrudnianie pracownika w okresie wypowiedzenia niesie ze sobą ryzyko naruszenia czy zagrożenia słusznego interesu pracodawcy.

mgr Joanna Łukaszczuk

Uniwersytet im. Adama Mickiewicza w Poznaniu

\section{RELEASE OF AN EMPLOYEE FROM THE OBLIGATION TO WORK DURING THE NOTICE PERIOD}

\section{Summary}

The paper presents the institution of a release of an employee from the obligation to perform work during the notice period (so called 'garden leave'). Such an institution is a result of an economic practice, supported by the views of legal doctrine and the judiciary. A lack of a legal regulation to govern it provokes many doubts concerning e.g. the possibility to release an employee from work unilaterally, in employer's sole discretion, the amount of remuneration received by the employee during garden leave and the employer's right to withdraw such release. In this paper the author considers the legal issues of the presented institution such as its conformity with the nature of employment relationship and the labour law, the potential reasons of its application as well as its legal status and effects. A fundamental proposition formulated in the paper is formulation of a comprehensive regulation of this institution in the Labour Code. The Author suggests that the employer's right to release the employee from the obligation to perform work during the notice period should be limited to events when performing work by the employee during the notice period carries a risk of violation or a threat to the justified interests of the employer. 
